\title{
A novel metronomic chemotherapy regimen of weekly platinum and daily oral etoposide in high-risk non-small cell lung cancer patients
}

\author{
P. CORREALE ${ }^{1}$, D. CERRETANI ${ }^{2}$, C. REMONDO ${ }^{1}$, I. MARTELLUCCI ${ }^{1}$, S. MARSILI $^{1}$, M. LA PLACA ${ }^{1}$,

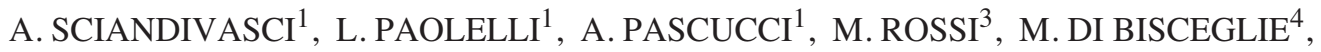 \\ G. GIORGI ${ }^{2}$, G. GOTTI ${ }^{4}$ and G. FRANCINI ${ }^{1}$
}

\begin{abstract}
${ }^{1}$ Section of Oncology, Department of Human Pathology and Oncology, Siena University School of Medicine; ${ }^{2}$ G. Segre Department of Pharmacology, Siena University School of Medicine; ${ }^{3}$ Respiratory Physiopathology Unit, Policlinico Santa Maria delle Scotte; ${ }^{4}$ Thoracic Surgery Unit, Siena University School of Medicine, Viale Bracci 11, 53100 Siena, Italy
\end{abstract}

Received February 14, 2006; Accepted March 3, 2006

\begin{abstract}
Absract. The aim of this pilot phase II trial was to investigate the toxicity and anti-tumour activity of a novel metronomic regimen of weekly cisplatin (CDDP) and oral etoposide (VP16) in high-risk patients with advanced NSCLC. The study enrolled 31 high-risk patients (27 men and 4 women aged 16-82 years; mean, 64.3) with NSCLC (18 stage IIIB and 13 stage IV) and an ECOG performance status of $\leq 3$, all of whom received weekly CDDP $30 \mathrm{mg} / \mathrm{m}^{2}$ iv on days $1,8,14$ and 28 of each cycle and oral daily etoposide $50 \mathrm{mg} / \mathrm{m}^{2}$ on 21 of the 28 days. The most frequent adverse events were grade III leukopenia and anemia; nevertheless, three patients died of pulmonary embolism after 2, 3 and 6 weeks of treatment. The objective response (OR) rate was $45.2 \%$ (2 complete and 12 partial), and the disease control rate was $58.1 \%$ (14 ORs and 4 disease stabilisations). The mean time to progression and survival were respectively nine months (95\% CI, 6.3-15.8 months) and thirteen months (95\% CI, 9.1-20.5 months). Pharmacological analysis showed that this metronomic regimen allows a much greater median monthly area under the curve of CDDP and VP16 than conventional treatment schedules. Our findings also suggest that this treatment schedule may affect tumour growth and neoangiogenesis by changing peripheral blood vascularendothelial growth factor levels. These preliminary results indicate that our metronomic regimen is well tolerated and active, even in patients with a very poor prognosis.
\end{abstract}

Correspondence to: Professor Guido Francini, Section of Medical Oncology, Department of Human Pathology and Oncology, Siena University School of Medicine, Viale Bracci 11, 53100 Siena, Italy E-mail: correale@unisi.it

Key words: metronomic-chemotherapy, NSCLC, oral-VP16, weekly-CDDP, pharmacokinetics, VEGF

\section{Introduction}

Non-small cell lung cancer (NSCLC) is the most common malignancy in humans and the leading cause of cancer death worldwide (1-3). There are nearly 350,000 new NSCLC patients every year in Western countries, $55 \%$ of whom present with stage IIIB or IV disease and cannot undergo curative radical surgery; furthermore, one-third of patients treated with curative intent due to being diagnosed with early-stage disease will relapse and eventually succumb to the disease. All patients with advanced or relapsed disease have a poor prognosis and usually die within one year, with an overall median survival of 8-11 months. Only one-third of patients diagnosed with advanced disease live for one year, and only $10-21 \%$ live for two years (3).

The high rate of mortality associated with the disease is due to the remarkable chemo-refractoriness and metastatic potential of lung cancer cells. The results of a number of trials have shown that the most effective regimens for treating advanced NSCLC must contain cisplatin (CDDP) or other platinum derivatives in combination with a second cytotoxic drug such as the type II topoisomerase inhibitor, etoposide (VP16); the vinca alkaloid, vinorelbine (VNB); the nucleoside antimetabolite, gemcitabine (GEM); or the cytoskeleton inhibitors, docetaxel or paclitaxel (3-18).

Multiple studies testing these two-drug regimens have shown different objective response rates (12-35\%) but comparable results in terms of time to progression (4.5-7 months) and overall survival (7-10 months), with an average 1-year survival of 30-35\% and 5-year survival of less than 10\% (3-18). In brief, a number of studies indicate that platinum-based chemotherapy can be considered the standard treatment for advanced NSCLC as it is associated with a cost-efficient reduction in mortality in the first six months and slight overall survival prolongation.

These studies have also shown that a good performance status and the possibility of receiving full-dose CDDP (80$100 \mathrm{mg} / \mathrm{m}^{2}$ ) lead to a greater likelihood of achieving an objective response and clinical improvement $(3-8,19)$, but this is a major problem in clinical oncology because NSCLC 
very often develops in elderly patients who have been longterm smokers and high-risk workers. As a result, they are frequently also affected by severe non-neoplastic cardiopulmonary diseases, such as chronic obstructive pulmonary disease (COPD), lung fibrosis, coronary disease, and hypertension-associated cardiac hypertrophy $(3,20)$, that often further impair their clinical condition and worsen their performance status $(3,9,11-12,20,21)$. It is for this reason that many NSCLC patients that are considered as having a very poor prognosis are excluded from receiving effective medical cancer treatment.

The results of more recent studies indicate that many cytotoxic drugs administered daily or weekly at lower doses (metronomic schedules) may be much better tolerated and lead to greater anti-tumour effects. These authors suggest that, used in this way, the same drugs, in addition to their specific mechanisms of tumour cell killing, become capable of modulating the tumour cell phenotype and disrupting tumour-associated angiogenic processes (22-26). We hypothesised that high-risk NSCLC patients may benefit from these results and, thus, evaluated the toxicity and anti-tumoral activity of a novel metronomic regimen based on weekly intravenous (iv) CDDP and daily oral VP16. The patients were considered at high risk if they had a major cancerassociated pulmonary or cardiological disease, an ECOG performance status of $\geq 2$, or were $>70$ years old. We decided to investigate the combination of CDDP and VP16 because it is considered to be highly synergistic in vitro and in vivo, active in the treatment of NSCLC, and also because it has been the standard treatment for NSCLC for several years (3) and is 10-100 times less expensive than the majority of newest drug combinations. However, especially in elderly patients, its use has been hampered by the occurrence of hematological toxicity, which often prevents the administration of full doses or requires the substitution of CDDP with its analogue, carboplatin (4-8). We also chose this combination because VP16 may be given orally and has a good safety profile (16-17), and its chronic administration can affect angiogenesis. CDDP was chosen instead of its carboplatin analogue because it is considered more active in NSCLC (27) and has a pattern of toxicity that better suits its combination with VP16. Finally, there are published findings that multi-drug regimens including weekly low-dose CDDP administration in elderly NSCLC patients are both active and well tolerated (18).

\section{Patients and methods}

Patients. The study enrolled 31 patients with a histological diagnosis of NSCLC (Table I), all of whom had advanced disease, an ECOG performance status of $\leq 3$, and a life expectancy of $\geq 3$ months. Study enrolment required normal renal and hepatic function, a white blood cell (WBC) count of $>2500 / \mathrm{mm}^{3}$, hemoglobin levels of $>9 \mathrm{mg} / \mathrm{mm}^{3}$, a platelet cell count of $>90,000 / \mathrm{mm}^{3}$, and a cardiac ejection fraction of $>46 \%$. The exclusion criteria were uncompensated valvular and wall motion abnormalities or arrhythmias, central nervous system (CNS) involvement, second tumours, uncompensated liver or other renal abnormalities, active infectious disease, or a history of other severe uncompensated cardiovascular diseases. The study was approved by our local ethics committee, and was performed in accordance with the applicable good clinical practice (GCP) guidelines. All of the patients gave written informed consent.

Study design. The study was designed to investigate the toxicity and activity of a new metronomic chemotherapy schedule combining weekly CDDP and oral VP16. In order to test the hypothesis that it is active in the treatment of patients with advanced high-risk NSCLC, at least 25 patients were required to maintain $\alpha$ and $B$ errors of respectively $5 \%$ and $20 \%$. As the pharmacological response rate in patients with high-risk NSCLC is $<25 \%$, the study was to be terminated if no clinical response was found in at least two (20\%) of the first 10 consecutively enrolled patients.

Patient treatment. Thirty-one NSCLC patients gave written informed consent and received treatment with intravenous CDDP $30 \mathrm{mg} / \mathrm{m}^{2}$ on days $1,8,14$ and 28 of each cycle, and oral VP16 $50 \mathrm{mg} / \mathrm{m}^{2}$ on 21 days of each 28 -day cycle. All of the patients received standard mannitol, corticosteroid, antiemetic and gastroprotective medication before CDDP.

Baseline and on-treatment clinical assessments. Before treatment, a complete history was taken of all of the patients, who also underwent a physical examination, complete blood count, serum chemistry tests, and complete disease staging by means of chest X-rays, brain, chest and abdominal computed tomography (CT), and liver and pelvis echography. As most of the patients were affected by concomitant smoking-associated cardiopulmonary diseases, all of them also underwent ultrasound investigation of left ventricular function and pulmonary volume analyses.

The staging examinations were repeated every two months, whereas full blood counts, biochemistry profile, liver function tests, electrocardiography (ECG), chest X-rays and urine analyses were repeated weekly.

Toxicity and response criteria. All of the eligible patients were evaluated for survival and toxicity, and considered evaluable for response if they had completed three treatment cycles. The patients who responded or had stable disease continued the treatment until the occurrence of disease progression or unacceptable toxicity. Overall survival was measured from the date of diagnosis to the date of death or the date of the last follow-up examination. Time to progression was evaluated from the beginning of treatment to the demonstration of disease progression or the date of the last follow-up examination. Response and toxicity were assessed using standard WHO criteria. A complete response was defined as the complete disappearance of all known measurable disease for at least one month, and a partial response as a decrease of almost $50 \%$ in known lesions lasting for at least one month. The area of two-dimensional lesions was defined as the product of the longest diameter multiplied by the greatest perpendicular diameter; disease stabilisation was defined as a $<50 \%$ decrease or $<25 \%$ increase in evaluable lesions lasting for one month without the appearance of new lesions, and progressive disease as a $>25 \%$ increase in known disease or the appearance of new lesions (WHO criteria).

Pharmacokinetic study. Ten patients underwent pharmacokinetic study during treatment; the control group consisted of 
10 patients receiving conventional infusional VP-16 and CDDP. Serial blood samples were drawn before and 0.25, 0.5, $1,2,3$ and $6 \mathrm{~h}$ after oral intake (days 1,8 and 21) or the end of infusion (days 1,2 and 3) from the contralateral arm. The plasma was separated by means of centrifugation (3000 x g for $5 \mathrm{~min}$ ) and stored at $-70^{\circ} \mathrm{C}$ until analysed for VP16 using a previously described reversed-phase HPLC method (28).

Statistical and pharmacokinetic analysis. The data were expressed as the mean cumulative AUC (calculated as AUC $\mathrm{x}$ days of treatment) \pm standard deviation (SD) after 1-21 days of oral or 1-3 days of intravenous VP16 administration.

The pharmacokinetic parameters of VP16, $\mathrm{t}_{1 / 2}$ (terminal half-life), AUC (area under the curve in the dose interval), $\mathrm{C}_{\max }$ (peak plasma level) and $\mathrm{T}_{\max }$ (time to peak), were computed using standard non-compartmental methods (29).

VEGF assay. VEGF was measured using a human VEGF sandwich ELISA kit (Chemicon International) as suggested by the manufacturer. The assays were performed on $100 \mu \mathrm{l}$ of peripheral blood serum taken from ten study patients at baseline, and $72 \mathrm{~h}$ and 60 days after the start of treatment; the control was peripheral blood serum from 10 NSCLC patients receiving the standard infusional VP16 and CDDP regimen.

\section{Results}

Study design. The primary study endpoints were the response rate and time to progression (TTP); the secondary endpoints were the frequency of adverse events and overall survival. This was a classic two-step clinical trial that foresaw early discontinuation in the absence of at least two responses in the first 10 patients (20\%), and an estimated final enrolment of at least 25 patients with a response rate higher than $25 \%$ for the treatment to be considered active. The drug doses and schedule were chosen on the basis of the results of previous studies of weekly CDDP and daily oral VP16 $(30,31)$ as palliative monochemotherapy; they were also extrapolated from previous phase I-II dose escalation studies showing the safety of the combination (unpublished results).

Patient population. The study enrolled 31 patients (27 men and 4 women, aged 43-82 years; mean, 64.3 years) with NSCLC (18 stage IIIB, 13 stage IV) and an ECOG performance status of 0-3 (eight ECOG 0, twelve ECOG 1; eight ECOG 2 and three ECOG 3) between February 2002 and February 2005. Fifteen patients showed significant weight loss at the time of enrolment, and all reported a cough, hemoptysis or dyspnea.

Thirteen patients were more than 70 years old; 15 had long-lasting, high-grade chronic obstructive pulmonary disease (which had evolved into symptomatic peripheral lung emphysema in seven cases); six had significant heart disease (2 coronary ischemic disease, 2 hypertension-associated cardiac hypertrophy, and 2 had a pump defect with left heart insufficiency); and two showed pulmonary embolism at the baseline (before any treatment).

Ten patients had received a previous line of treatment. At the time of enrolment, all of the patients had advanced disease (stage IIIB-IV), and 10 of them had multiple metastatic sites (lung, liver, soft tissue and bone).
Table I. Patient characteristics.

\begin{tabular}{|c|c|}
\hline Characteristics & Number \\
\hline $\begin{array}{l}\text { Enrolled patients } \\
\text { (Evaluable for toxicity) }\end{array}$ & 31 \\
\hline Evaluable for response & 28 \\
\hline $\begin{array}{l}\text { Gender } \\
\text { Male } \\
\text { Female }\end{array}$ & $\begin{array}{r}27 \\
4\end{array}$ \\
\hline $\begin{array}{l}\text { Stage } \\
\text { IIIB } \\
\text { IV }\end{array}$ & $\begin{array}{l}18 \\
13\end{array}$ \\
\hline $\begin{array}{l}\text { Serious associated non-n } \\
\text { Present } \\
\text { Absent }\end{array}$ & $\begin{array}{r}23 \\
8\end{array}$ \\
\hline Cardiological disease & 6 \\
\hline $\begin{array}{l}\text { Pulmonary disease } \\
\text { grade I-II } \\
\text { grade III }\end{array}$ & $\begin{array}{l}8 \\
7\end{array}$ \\
\hline $\begin{array}{l}\text { Performance status } \\
0-1 \\
2 \\
3\end{array}$ & $\begin{array}{r}20 \\
8 \\
3\end{array}$ \\
\hline $\begin{array}{l}\text { Age } \\
\quad<70 \\
\geq 70\end{array}$ & $\begin{array}{l}13 \\
18\end{array}$ \\
\hline
\end{tabular}

Mean age, 64.3 years (range, $46-82$ years)

Toxicity. The patients received a median of 20 weeks of treatment (range, 4-24 weeks). Three died of pulmonary embolism after respectively two, three and six weeks of treatment. The treatment was very well tolerated by the others, and no grade 4 toxicity was recorded; the most frequent adverse events were grade III leukopoenia and anemia. A moderate and reversible increase in transaminase levels was observed in four patients, and cardiac arrhythmia (supraventricular fibrillation) in one; there were no episodes of hyper- or hypotension. Reversible and moderate creatinine and BUN abnormalities were recorded in two patients after 5-8 treatment cycles.

All of the patients received full CDDP doses but a $25 \%$ reduction in the VP16 dose was required in seven patients because of persistent hematological toxicity or increased transaminases. One patient who achieved a pathological complete response developed bilateral idiopathic aseptic hip osteonecrosis six months after the end of the treatment (Table II).

Clinical responses. As this was an intent-to-treat study, all of the patients were considered in this analysis (Table III). The objective response rate was $46.2 \%$ ( 2 complete and 12 partial responses) and the disease control rate was $58.1 \%$ (14 objective responses and 4 disease stabilisations); three patients died before undergoing instrumental re-evaluation and, in ten, the 
Table II. Toxicity (31 patients).

\begin{tabular}{llrrr}
\hline Grade & I & II & III & IV \\
\hline Leukopenia & - & 7 & 7 & - \\
Anemia & - & 5 & 10 & - \\
Thrombocytopenia & - & 7 & 3 & - \\
Increased transaminases & - & 2 & 2 & - \\
Supraventricular fibrillation & - & & 2 & - \\
$\begin{array}{l}\text { Creatinine and BUN } \\
\text { abnormalities }\end{array}$ & - & 1 & 3 & \\
$\begin{array}{l}\text { Bilateral idiopathic aseptic } \\
\text { hip osteonecrosis }\end{array}$ & & & & \\
\end{tabular}

The patients received a median of 20 weeks of treatment (range, 424 weeks). Three patients died of pulmonary embolism after two, three and six weeks of treatment. One case of bilateral aseptic bone necrosis was observed in one of the two patients achieving a complete response; surgery revealed no metastatic involvement.

disease progressed. The median time to progression and survival was respectively 9 months (95\% CI, 6.3-15.8 months) and 13 months (95\% CI, 9.1-20.5). The average follow-up of these patients was 19 months; 4 patients (13\%, two stage IIIB and two stage IV) who achieved an objective response were alive 32 months after enrolment.

Six patients with stage IIIb NSCLC who achieved a considerable objective response were administered radiotherapy (40-45 Gy in 4-5 weeks) after 24 weeks of chemotherapy, which led to a further improvement in response. Four of them experienced post-actinic pneumonitis which reversed with corticosteroids; and one underwent lobectomy and was found to have a complete pathological response.

Pharmacokinetic study. In an attempt to explain the high response rate and long time to progression, we performed a pharmacokinetic analysis aimed at investigating whether the regimen improved the patients' systemic exposure to the cytotoxic drugs. The pharmacokinetic parameters of oral and iv $\operatorname{VP16}\left(\mathrm{C}_{\max }, \mathrm{T}_{\max }, \mathrm{t}_{1 / 2}\right.$ and cumulative AUC) are shown in Table IV. The analysis showed that the VP16 maximal blood concentration defined $\mathrm{C}_{\max }$ was significantly less in patients who received the metronomic regimen (range, 1.09-5.11 $\mu \mathrm{g} / \mathrm{ml}$ ) than in those who received the conventional iv schedule (range, 10.26-26.3 $\mu \mathrm{g} / \mathrm{ml}$ ). The time needed to achieve the maximal concentration defined as $\mathrm{T}_{\max }$ was $120 \mathrm{~min}$ after oral administration and 60 min after iv infusion; the terminal half-life in the two groups was respectively $286.4+62.96$ and 253.5+66.64 $\mathrm{min}$.

On the other hand, the cumulative monthly VP16 average AUC (and therefore the drug bioavailability) was much greater in patients who received the metronomic regimen (Fig. 1). These results were statistically significant even though a considerable inter-patient variation in the pharmacokinetic parameters was detected $(\mathrm{P}<0.05)$.

VEGF monitoring during metronomic treatment. In order to investigate the possible anti-angiogenic effects of the metronomic schedule reported in a number of preclinical studies, we monitored peripheral blood VEGF levels (Fig. 2). These decreased during the study treatment in 10 patients (with the reduction becoming significant after $72 \mathrm{~h}$ of therapy) but increased in 10 control patients receiving the conventional iv CDDP and VP16 regimen. These results suggest that our treatment schedule may also affect tumour growth and neoangiogenesis by changing VEGF levels.

\section{Discussion}

We here report the results of a phase II trial of a novel metronomic treatment schedule with weekly CDDP and oral VP16 in patients with advanced NSCLC. The treatment was well tolerated and proved to be very active insofar as it led to a high rate of objective responses (45.2\%) and disease control $(58.1 \%)$, associated with a clinical benefit in the majority of the patients. These results are particularly interesting as the protocol was investigated in a category of high-risk patients usually considered as having a very poor prognosis $(21,31-32)$.

We believe that the differences between our results and those published in the literature are at least partly due to the fact that elderly patients or patients with major lung cancerassociated diseases are too easily considered unable to receive systemic treatments or, even worse, are treated with suboptimal doses of cytotoxic drugs. However, it has been repeatedly shown that both elderly and younger patients with advanced NSCLC can receive equal benefit from medical treatment if their cancer-associated diseases are kept under medical control (Langer CJ, et al, Proc Am Soc Clin Oncol 22: abs. 639, 2003; and 33-36). Closer collaboration among a team of specialists (geriatrists, cardiologists and/or pneumologists) could allow the clinical stabilisation and rescue of many patients who could eventually receive efficacious palliative chemotherapy $(21,32,36,37)$.

Our treatment schedule was designed with the specific intent of administering full doses of CDDP and VP16 while

Table III. Anti-tumour activity.

\begin{tabular}{cccccccc}
\hline $\begin{array}{l}\text { No. of } \\
\text { patients }\end{array}$ & $\begin{array}{c}\text { Complete } \\
\text { response }\end{array}$ & $\begin{array}{c}\text { Partial } \\
\text { response }\end{array}$ & $\begin{array}{c}\text { Stable } \\
\text { disease }\end{array}$ & $\begin{array}{c}\text { Progressive } \\
\text { disease }\end{array}$ & $\begin{array}{c}\text { Unevaluable due } \\
\text { to early death }\end{array}$ & $\begin{array}{c}\text { Overall } \\
\text { response }\end{array}$ & $\begin{array}{c}\text { Disease } \\
\text { control }\end{array}$ \\
\hline 31 & 2 & 12 & 4 & 10 & 3 & 14 & $14+4$ \\
$100 \%$ & $6 \%$ & $39 \%$ & $13 \%$ & $32 \%$ & $9.6 \%$ & $45 \%$ & $58 \%$ \\
\hline
\end{tabular}

Mean time to progression and overall survival were respectively nine and thirteen months. 
Table IV. Plasma pharmacokinetic parameters of oral and i.v. etoposide.

\begin{tabular}{lcc}
\hline & oral $(\mathrm{n}=10)$ & iv $(\mathrm{n}=10)$ \\
\hline $\mathrm{C}_{\max }(\mu \mathrm{g} / \mathrm{ml})$ & $2.8 \pm 1.28$ & $16.9 \pm 6.54$ \\
$\mathrm{~T}_{\max }(\min )$ & 60 & 120 \\
$\mathrm{t}_{1 / 2}(\min )$ & $286.4 \pm 62.96$ & $253.5 \pm 66.64$ \\
$\begin{array}{l}\text { Cumulative AUC } \\
(\mu \mathrm{g} . \mathrm{min} / \mathrm{ml})\end{array}$ & $14090.6 \pm 5936.48^{\mathrm{a}}$ & $9639.36 \pm 1883.57$ \\
\end{tabular}

${ }^{\mathrm{a}} \mathrm{p}<0.05$. Values are mean $\pm \mathrm{SD} . \mathrm{C}_{\max }=$ peak plasma concentration; $\mathrm{T}_{\max }=$ peak time; $\mathrm{t}_{1 / 2}=$ terminal half-life $; \mathrm{AUC}=$ area under the etoposide plasma concentration-time curve; Cumulative $\mathrm{AUC}=$ mean AUC $\mathrm{x}$ days of etoposide.

sparing as much as possible the urinary apparatus and cardiovascular system. The treatment strategy allows the administration of a monthly CDDP dose intensity that is equal to or more than that provided by the more conventional polychemotherapy schedules considered active against NSCLC. These regimens usually use VP16 or a new-generation drug (GEM, VNB or the taxanes) in combination with intravenous CDDP infusions of $80-100 \mathrm{mg} / \mathrm{m}^{2}$ on days $1-2$ of repeated 21 to 28-day cycles (3-18). Different methods of administration may lead to completely different patterns of toxicity and antitumour activity as pharmacokinetic factors are critical for both. In this context, the AUC of VP16 is strictly related to its anti-tumour activity (38). In this phase II trial, we carried out a parallel VP16 pharmacokinetic study in some of these patients, finding that the monthly cumulative VP16 AUC throughout the course of metronomic treatment was significantly greater than that achieved in a control group of ten NSCLC patients treated with the iv schedule, thus suggesting that the former led to much greater systemic drug exposure per month. This enhanced drug bioavailability was achieved without any additional occurrence of side effects, probably because the VP16 $\mathrm{C}_{\max }$ in patients receiving the metronomic schedule was significantly lower than that detected in patients receiving the conventional iv schedule. Higher plasma levels of VP16 are in fact associated with greater toxicity and not with better outcomes. Clark et al (39) suggested that the duration of exposure to lower drug levels $(<2 \mu \mathrm{g} / \mathrm{ml})$ may be important in terms of anti-tumour efficacy, whereas hematological toxicity may require slightly higher drug concentrations ( $>3 \mu \mathrm{g} / \mathrm{ml}$ ). In this context, metronomic administration offers a pharmacological advantage as it allows greater systemic exposure to be achieved within the month, whilst maintaining relatively low daily plasma VP16 levels.

We also found that the metronomic regimen allowed the whole treatment to be administered without toxicity-related delays insofar as $90 \%$ of the patients completed the treatment cycle within 28 days, compared to the $60-70 \%$ recorded with more conventional regimens. This suggests that the use of weekly CDDP and oral VP16 delivers both greater dose intensity and greater dose density, a new pharmacological

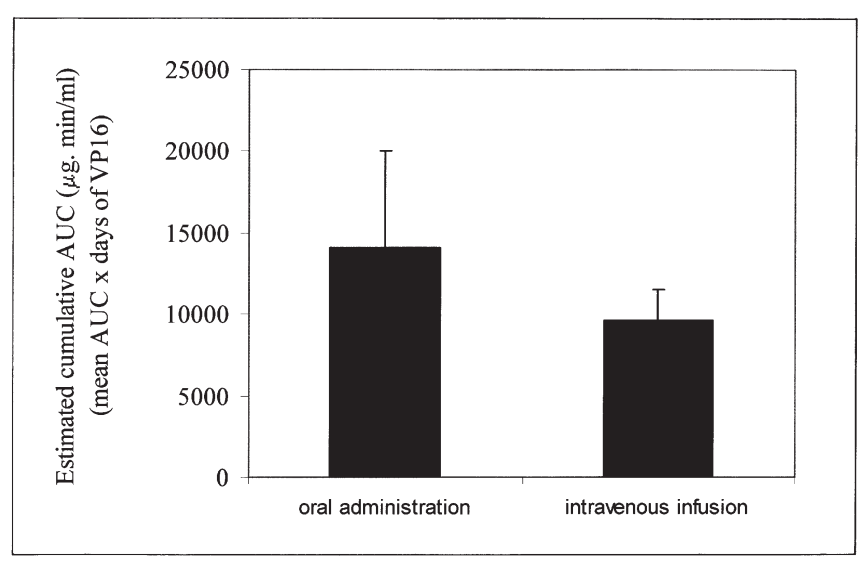

Figure 1. Estimated monthly cumulative AUC (entire cycle course) of oral VP16 administration versus infusion in patients respectively receiving metronomic and conventional iv treatment.

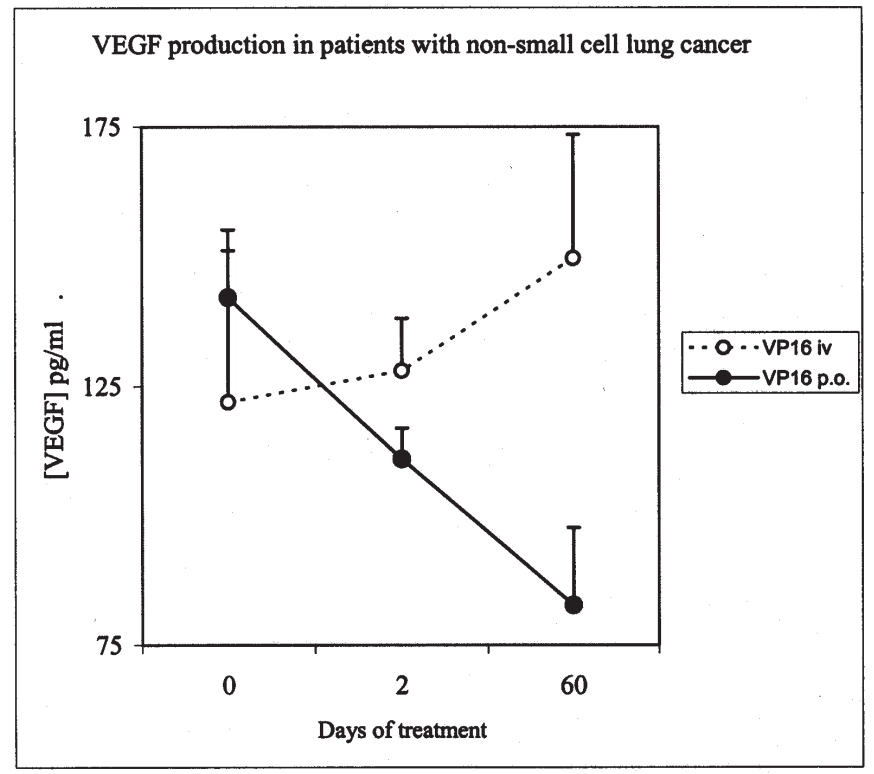

Figure 2. Peripheral blood VEGF levels in ten patients receiving VP16 and CDDP by means of the metronomic $(\bullet)$ or conventional intravenous schedule $(0)$.

concept initially derived from breast cancer studies showing that patients receiving cytotoxic drugs with a shorter intercycle interval and no delay had a better prognosis $(36-37,40)$. This finding was explained on the grounds that a longer resting period between two chemotherapy cycles promotes drugresistant clones rising and leads to greater cancer recovery (40).

The role of dose-density has also been investigated in NSCLC patients, and the results led to clinical trials of the latest weekly taxane-based treatment schedules (41). This trend has been criticised since a phase III trial of weekly paclitaxel combined with carboplatin failed to demonstrate any survival advantage over the conventional 3-weekly schedule (27). However, although these results need to be considered when designing new studies, the limitation may be specifically related to the unique pharmacological properties of paclitaxel and carboplatin $(27,40,41)$. 
Another aspect that deserves consideration is that conventional cytotoxic drugs were developed with the intent of treating cancer by means of direct killing or by inhibiting the growth of cycling tumour cells, whereas there is increasing evidence that lower cytotoxic drug doses given at shorter rhythmic (metronomic) intervals may affect tumor growth in vivo by means of completely different mechanisms of action that interfere with tumour/host interactions at different levels (26,42-53). For example, the metronomic use of several drugs may have a powerful anti-angiogenic effect by directly damaging newly formed tumour-associated vessels or by killing the proliferating endothelial stem cells that affect the formation of new vessels, which in turn sustain tumour expansion (22-25). In this context, Man et al have recently shown that the chronic (metronomic) administration of daily low-dose cyclophosphamide (CTX) is safe and efficacious in immune-compromised SCID mice inoculated with different cell types; their model shows that metronomic chemotherapy regimens may target multiple tumour-associated cell types (52), including endothelial and drug-sensitive tumour cells, as well as other constituents contributing to the final tumour phenotype (53).

The preliminary results of a number of other groups currently investigating this kind of approach in both preclinical and clinical contexts show that very low doses of many cytotoxic drugs, such as VP16, anthracyclines, taxanes, CTX, GEM and CDDP, may have biomodulating effects on the neoplastic cell phenotype, the host micro-environment and the immune system, which may lead to efficacious anti-tumour effects $(22-25,52)$.

This non-canonic use of chemotherapy may not be counterbalanced by the occurrence of drug-resistant neoplastic clones because it targets normal tumour-associated cells, such as tumour-induced endothelial cells, that are genetically much more stable than their inducers (cancer cells) $(9-10,14,20,22-25)$. Man et al investigated the mechanisms of resistance to the metronomic modality in their model, and their preliminary results show no sign of acquired resistance (in PC3 prostate carcinoma cells), thus suggesting the occurrence of a CTX-altered host mechanism that involves altered drug metabolism by host liver enzymes (53) or changes in tumour vessel substrates. The same authors have shown that the CTX-based metronomic regimen synergistically interacts with other classes of anti-angiogenic drugs, which also suggests that other chemotherapeutic drugs may be similarly efficacious when delivered using metronomic dosing schedules $(26,42-49,53)$.

In our study, we also found a significant reduction in VEGF levels during treatment, which may definitely improve the antiangiogenic effects of metronomic chemotherapy. This effect was not observed in NSCLC patients receiving the conventional intravenous treatment schedule. The anti-angiogenic approach is currently considered one of the most promising therapeutic approaches to NSCLC, and some of the newest biological drugs (monoclonal antibodies such as Avastin ${ }^{\circledR}$, and thyrosine kinase inhibitors) are being tested in NSCLC patients (54-58). Furthermore, the ECOG 4599 trial has recently provided promising preliminary data in terms of survival when the carboplatin/paclitaxel doublet regimen is combined with the Avastin ${ }^{\circledR}$ anti-VEGF monoclonal antibody (58).
On the basis of the clinical results obtained with our metronomic VP16 and CDDP regimen, its low toxicity level, and the very low cost of treatment (50-100 times less than that of the most widely used polychemotherapy strategies), we propose the investigation of our metronomic regimen in combination with a third-generation anti-angiogenic drug; and the designing of a phase III trial aimed at comparing this regimen with the standard treatment in high-risk patients with stage $\mathrm{IIIB}^{+}$and stage IV NSCLC.

\section{References}

1. Minna JD, Pass J, Glatstein E and Ihde DC: Cancer of the lung. In: Cancer: Principles and Practice of Oncology. De Vita VTJ, Hellman S and Rosenberg SA (eds). JB Lippincott Co., Philadelphia, pp591-705, 1989.

2. Ihde DC and Minna JD: Non-small cell lung cancer. Part I. Biology, diagnosis, and staging. Curr Probl Cancer 15: 61-104, 1991.

3. Schrump DS, Altorki NK, Henschke CL, Carter D, Turrisi AT and Gutierrez ME: Cancer of the Lung: Section 2: Non-Small Cell Lung Cancer. In: Cancer: Principles and Practice of Oncology. De Vita VTJ, Hellman S and Rosenberg SA (eds). Lippincott Williams and Wilkins, Philadelphia, pp753-777, 2005.

4. Bunn PA Jr and Kelly K: New chemotherapeutic agents prolong survival and improve quality of life in non-small cell lung cancer: a review of the literature and future directions. Clin Cancer Res 4: 1087-1100, 1998.

5. Shepherd FA: Treatment of advanced non-small cell lung cancer. Semin Oncol 21 (suppl 7): 7-18, 1994.

6. Depierre A, Lagrange JL, Theobald S, Astoul P, Baldeyrou P, Bardet E, Bazelly B, Brechot JM, Breton JL, Douillard JY, Grivaux M, Jacoulet P, Khalil A, Lemarie E, Martinet Y, Massard G, Milleron B, Molina T, Moro-Sibilot D, Paesmans M, Pujol JL, Quoix E, Ranfaing E, Riviere A, Sancho-Garnier H, Souquet PJ, Spaeth D, Stoebner-Delbarre A, Thiberville L, Touboul E, Vaylet F, Vergnon JM and Westeel V: FNCLCC summary report of the standards, options and recommendations for the management of patients with non-small-cell lung carcinoma (2000). Br J Cancer 89 (suppl 1): S35-S49, 2003.

7. Johnson DH: Treatment strategies for metastatic non small-cell lung cancer. Clin Lung Cancer 1: 34-41, 1999.

8. Vokes EE and Bitran JD: Non-small-cell lung cancer. Toward the next plateau. Chest 106: 659-661, 1994.

9. Rapp E, Pater JL, Willan A, Cormier Y, Murray N, Evans WK, Hodson DI, Clark DA, Feld R, Arnold AM, et al: Chemotherapy can prolong survival in patients with advanced non-small-cell lung cancer - report of a Canadian multicenter randomized trial. J Clin Oncol 6: 633-641, 1988.

10. Souquet PJ, Chauvin F, Boissel JP, Cellerino R, Cormier Y, Ganz PA, Kaasa S, Pater JL, Quoix E, Rapp E, et al: Polychemotherapy in advanced non-small cell lung cancer: a metaanalysis. Lancet 342: 19-21, 1993.

11. Sandler A: First line combination chemotherapy for advanced non small cell lung cancer: The Eastern Cooperative Oncology Group and Southwest Oncology Group experience. Seminar Oncol 26 (suppl 15): 44-51, 1999.

12. Bengtson EM and Rigas JR: A brief historical review of the development of chemotherapy for the treatment of advanced non-small cell lung cancer: why we should look beyond platinum. Semin Oncol 26 (suppl 16): 1-6, 1999.

13. Cardenal F, Lopez-Cabrerizo MP, Anton A, Alberola V, Massuti B, Carrato A, Barneto I, Lomas M, Garcia M, Lianes P, Montalar J, Vadell C, Gonzalez-Larriba JL, Nguyen B, Artal A and Rosell R: Randomized phase III study of gemcitabinecisplatin versus etoposide-cisplatin in the treatment of locally advanced or metastatic non-small-cell lung cancer. J Clin Oncol 17: 12-18, 1999 .

14. Bonomi P, Kim K, Fairclough D, Cella D, Kugler J, Rowinsky E, Jiroutek $M$ and Johnson D: Comparison of survival and quality of life in advanced non small cell lung cancer patients treated with two dose levels of paclitaxel combined with cisplatin versus etoposide with cisplatin: results of an Eastern Cooperative Oncology Group Trial. J Clin Oncol 8: 623-631, 2000 . 
15. Le Chevalier T, Brisgand D, Douillard JY, Pujol JL, Alberola V, Monnier A, Riviere A, Lianes P, Chomy P, Cigolari S, et al: Randomized study of vinorelbine and ciplatin versus vindesine and cisplatin versus vinorelbine alone in advanced non small cell lung cancer: results of a European multicenter trial including 612 patients. J Clin Oncol 12: 360-367, 1994.

16. Park J, Ahn YC, Kim H, Lee SH, Park SH, Lee KE, Lim do H, Park J, Kim K, Jung CW, Im YH, Kang WK, Lee MH and Park K: A phase II trial of concurrent chemoradiation therapy followed by consolidation chemotherapy with oral etoposide and cisplatin for locally advanced inoperable non-small cell lung cancers. Lung Cancer 42: 227-235, 2003.

17. D'Addario G, Pintilie M, Leighl NB, Feld R, Cerny T and Shepherd FA: Platinum-based versus non-platinum-based chemotherapy in advanced non-small-cell lung cancer: a meta-analysis of the published literature. J Clin Oncol 23: 2926-2936, 2005

18. Berardi R, Porfiri E, Scartozzi M, Lippe P, Silva RR, Nacciarriti D, Menichetti ET, Tummarello D, Carle F, Piga A and Cellerino R: Elderly patients with advanced non-small cell lung cancer. A phase II study with weekly cisplatin and gemcitabine. Oncology 65: 198-203, 2003.

19. Di Maio M, Gridelli C, Gallo C, Shepherd F, Piantedosi FV, Cigolari S, Manzione L, Illiano A, Barbera S, Robbiati SF, Frontini L, Piazza E, Ianniello GP, Veltri E, Castiglione F, Rosetti F, Gebbia V, Seymour L, Chiodini P and Perrone F: Chemotherapy-induced neutropenia and treatment efficacy in advanced non-small-cell lung cancer: a pooled analysis of three randomised trials. Lancet Oncol 6: 637-638, 2005.

20. Janssen-Heijnen MLG, Schipper RM, Razenberg PPA, et al: Prevalence of co-morbidity in lung cancer patients and its relationship with treatment; a population-based study. Lung Cancer 21: 105-113, 1998.

21. Janssen-Heijnen ML, Smulders S, Lemmens VE, Smeenk FW, van Geffen HJ and Coebergh JW: Effect of comorbidity on the treatment and prognosis of elderly patients with non-small cell lung cancer. Thorax 59: 602-607, 2004.

22. Bertolini F, S Paul, Mancuso P, Monestiroli S, Gobbi A, Shaked $\mathrm{Y}$ and Kerbel RS: Maximum tolerable dose and low dose metronomic chemotherapy have opposite effects on the mobilization and viability of circulating endothelial progenitor cells. Cancer Res 63: 4342-4346, 2003.

23. Emmenegger U, Man S, Shaked Y, Francia G, Wong JW, Hicklin DJ and Kerbel RS: A comparative analysis of low dose metronomic cyclophosphamide reveals absent or low grade toxicity on tissue highly sensitive to the toxic effects of maximum tolerated dose regimes. Cancer Res 64: 3994-4000, 2004.

24. Stolting S, Klink T, Bela C, Engels C and Wagner T: Metronomic scheduling of trofosfamide chemotherapy in human NSCLC xenografts highly increases therapeutic efficacy compared to conventional scheduling by inhibition of angiogenesis. Int J Clin Pharmacol Ther 42: 652-653, 2004.

25. Drevs J, Fakler J, Eisele S, Medinger M, Bing G, Esser N, Marme D and Unger C: Antiangiogenic potency of various chemotherapeutic drugs for metronomic chemotherapy. Anticancer Res 24: 1759-1763, 2004.

26. Comis RL, Friedland DM and Good BC: The role of oral etoposide in non-small cell lung cancer. Drugs 58 (suppl 3): 21-30, 1999.

27. Zatloukal P, Petruzelka L, Zemanova M, Kolek V, Skrickova J, Pesek M, Fojtu H, Grygarkova I, Sixtova D, Roubec J, Horenkova E, Havel L, Prusa P, Novakova L, Skacel T and Kuta M: Gemcitabine plus cisplatin vs. gemcitabine plus carboplatin in stage IIIb and IV non-small cell lung cancer: a phase III randomized trial. Lung Cancer 41: 321-331, 2003.

28. Freyer G, Ligneau B, Tranchand B, Ardiet C, Souquet PJ, Court-Fortune I, Riou R, Rebattu P, Morignat E, Boissel JP, Trillet-Lenoir V and Girard P: The prognostic value of etoposide area under the curve (AUC) at first chemotherapy cycle in small cell lung cancer patients: a multicenter study of the groupe Lyon-Saint-Etienne d'Oncologie Thoracique (GLOT). Lung Cancer 31: 247-256, 2001

29. Rowland M and Thomas NT: Clinical Pharmacokinetics, Concepts and Application. Philadelphia, William and Wilkins, 1996.

30. Abratt RP, Willcox PA and Salton DG: Concurrent radiation and weekly cisplatin for non-small-cell lung cancer - a phase I/II study. Cancer Chemother Pharmacol 30: 495-497, 1992.

31. Kurtz ME, Kurtz JC, Given CW and Given B: Predictors of use of health care services among elderly lung cancer patients: the first year after diagnosis. Support Care Cancer 14: 243-250, 2006 .
32. Batura-Gabryel H and Foremska-Iciek J: Lung cancer in the elderly - an increasing epidemiological problem of the $21 \mathrm{st}$ century. Rocz Akad Med Bialymst 50 (suppl 1): 152-155, 2005.

33. Gridelli C, Perrone F, Gallo C, et al: Chemotherapy for elderly patients with advanced non-small-cell lung cancer: the Multicenter Italian Lung Cancer in the Elderly Study (MILES) phase III randomized trial. J Natl Cancer Inst 95: 362-372, 2003.

34. Hensing TA, Peterman AH, Schell MJ, et al: The impact of age on toxicity, response rate, quality of life, and survival in patients with advanced, stage IIIb or IV non small cell lung carcinoma treated with carboplatin and paclitaxel. Cancer 98: 779-788, 2003.

35. Perrone F, Gallo C and Gridelli C: Cisplatin-based therapy for elderly patients with advanced non-small cell lung cancer: implications of Eastern Cooperative Oncology Group 5592 a randomized trial. J Natl Cancer Inst 94: 1029-1031, 2002.

36. Pfister DG, Johnson DH, Azzoli CG, et al: American Society of Clinical Oncology treatment of unresectable non-small-cell lung cancer guideline: update 2003. J Clin Oncol 22: 330-353, 2004.

37. Citron ML, Berry DA, Cirrincione C, Hudis C, Winer EP, Gradishar WJ, Davidson NE, Martino S, Livingston R, Ingle JN, Perez EA, Carpenter J, Hurd D, Holland JF, Smith BL, Sartor CI, Leung EH, Abrams J, Schilsky RL, Muss HB and Norton L: Randomized trial of dose-dense versus conventionally scheduled and sequential versus concurrent combination chemotherapy as postoperative adjuvant treatment of node-positive primary breast cancer: first report of Intergroup Trial C9741/Cancer and Leukemia Group B Trial 9741. J Clin Oncol 21: 1431-1439, 2003. Erratum in: J Clin Oncol 21: 2226, 2003.

38. Desoize B, Marechal F and Cattan A: Clinical pharmacokinetics of etoposide during 120 hours continuous infusions in solid tumours. Br J Cancer 62: 840-841, 1990.

39. Clark PI, Slevin ML, Joel SP, Osborne RJ, Talbot DI, Johnson PW, Reznek R, Masud T, Gregory W and Wrigley PF: A randomized trial of two etoposide schedules in small-cell lung cancer: the influence of pharmacokinetics on efficacy and toxicity. J Clin Oncol 12: 1427-1435, 1994.

40. Ramalingam S and Belani CP: Taxanes for advanced non-small cell lung cancer. Expert Opin Pharmacother 3: 1693-1709, 2002.

41. Socinski MA, Ivanova A, Bakri K, Wall J, Baggstrom MQ, Hensing TA, Mears A, Tynan M, Beaumont J, Peterman AH and Niell HB: A randomized phase II trial comparing every 3-weeks carboplatin/paclitaxel with every 3 -weeks carboplatin and weekly paclitaxel in advanced non-small cell lung cancer. Ann Oncol 17: 104-109, 2006.

42. Munoz R, Shaked Y, Bertolini F, Emmenegger U, Man S and Kerbel RS: Anti-angiogenic treatment of breast cancer using metronomic low-dose chemotherapy. Breast 14: 466-479, 2005.

43. Yap R, Veliceasa D, Emmenegger U, Kerbel RS, McKay LM, Henkin J and Volpert OV: Metronomic low-dose chemotherapy boosts CD95-dependent antiangiogenic effect of the thrombospondin peptide ABT-510: a complementation antiangiogenic strategy. Clin Cancer Res 11: 6678-6685, 2005.

44. Shaked Y, Emmenegger U, Francia G, Chen L, Lee CR, Man S, Paraghamian A, Ben-David Y and Kerbel RS: Low-dose metronomic combined with intermittent bolus-dose cyclophosphamide is an effective long-term chemotherapy treatment strategy. Cancer Res 65: 7045-7051, 2005.

45. Shaked Y, Emmenegger U, Man S, Cervi D, Bertolini F, Ben-David Y and Kerbel RS: The optimal biological dose of metronomic chemotherapy regimens is associated with maximum antiangiogenic activity. Blood 106: 3058-3061, 2005.

46. Ma L, Francia G, Viloria-Petit A, Hicklin DJ, du Manoir J, Rak J and Kerbel RS: In vitro procoagulant activity induced in endothelial cells by chemotherapy and antiangiogenic drug combinations: modulation by lower-dose chemotherapy. Cancer Res 65: 5365-5373, 2005.

47. Hudis CA: Clinical implications of antiangiogenic therapies. Oncology 19 (suppl 3): 26-31, 2005.

48. Kerbel RS and Kamen BA: The anti-angiogenic basis of metronomic chemotherapy. Nat Rev Cancer 4: 423-436, 2004.

49. Quesada AJ, Nelius T, Yap R, Zaichuk TA, Alfranca A, Filleur S, Volpert OV and Redondo JM: In vivo upregulation of CD95 and CD95L causes synergistic inhibition of angiogenesis by TSP1 peptide and metronomic doxorubicin treatment. Cell Death Differ 12: 649-658, 2005.

50. Ng SS and Figg WD: Upregulation of endogenous angiogenesis inhibitors: a mechanism of action of metronomic chemotherapy. Cancer Biol Ther 3: 1212-1213, 2004. 
51. Hanahan D and Weinberg RA: The hallmarks of cancer. Cell 100: 57-70, 2000.

52. Man S, Bocci G, Francia G, Green SK, Jothy S, Hanahan D, Bohlen P, Hicklin DJ, Bergers G and Kerbel RS: Antitumor effects in mice of low-dose (metronomic) cyclophosphamide administered continuously through the drinking water. Cancer Res 62: 2731-2735, 2002.

53. Jounaidi Y and Waxman DJ: Frequent, moderate-dose cyclophosphamide administration improves the efficacy of cytochrome P-450/cytochrome P-450 reductase-based cancer gene therapy. Cancer Res 61: 4437-4444, 2001.

54. Sandler A: Clinical experience with the HER1/EGFR tyrosine kinase inhibitor erlotinib. Oncology 17 (suppl 12): 17-22, 2003.

55. Sandler AB, Johnson DH and Herbst RS: Anti-vascular endothelial growth factor monoclonals in non-small cell lung cancer. Clin Cancer Res 10: 4258s-4262s, 2004.
56. Herbst RS and Sandler AB: Non-small cell lung cancer and antiangiogenic therapy: what can be expected of bevacizumab? Oncologist 9 (suppl 1): 19-26, 2004

57. Johnson DH, Fehrenbacher L, Novotny WF, Herbst RS, Nemunaitis JJ, Jablons DM, Langer CJ, DeVore RF III, Gaudreault J, Damico LA, Holmgren E and Kabbinavar F: Randomized phase II trial comparing bevacizumab plus carboplatin and paclitaxel with carboplatin and paclitaxel alone in previously untreated locally advanced or metastatic nonsmall-cell lung cancer. Clin Oncol 22: 2184-2191, 2004.

58. Tyagi P: Bevacizumab, when added to paclitaxel/carboplatin, prolongs survival in previously untreated patients with advanced non-small-cell lung cancer: preliminary results from the ECOG 4599 trial. Clin Lung Cancer 6: 276-278, 2005. 